quiet nature of the Sun and its large angular diameter at this frequency.

From the scintillation records, two points are evident. The first-the shadow patterns at 1,300 Mc./s. and $3,000 \mathrm{Mc} / \mathrm{s}$. (generated by the radiofrequency active areas on the Sun, which interfering with one another normally decrease the amplitude of the scintillations) are not dependent on frequency. This point is somewhat at variance with work reported by Kazès ${ }^{1}$. The second-within the distance between the centres of the two antennæ, a single shadow pattern exists. This latter observation is generally in accord with work of Steinberg and Kazès².

A more detailed analysis of the eclipse and scintillation data will appear at a later date.

Jules Aarons

John P. Castellit

RONALD M. STRaKa

WILLIAM C. KIDD

Air Force Cambridge Research Center, Bedford, Mass.

${ }^{1}$ C.R. Acad. Sci., Paris, 245, 636 (1957).

' ('R. Acad. Sci., Paris, 245, 782 (1957).

\section{Rare Hiss, Earth Currents and Micropulsations on November 27, 1959}

ON November 27, 1959, a rare signal was heard on the chorus-whistler equipment ${ }^{1}$ at College, Alaska. Beginning as a whistle of perhaps $2 \mathrm{kc} / \mathrm{s}$. at approximately 1351 A.S.T. (2351 G.M.T.) on November 27, 1959, a tone rose slowly to about $10 \mathrm{kc} . / \mathrm{s}$., becoming a hiss lasting for what seemed to be several minutes. At the same time magnetic field micropulsations ${ }^{2}$ with periods of 10-20 sec. were initiated with a commencement magnitude of about $2 \cdot 5 \gamma$ falling to $0.4 \gamma$ in about $5 \mathrm{~min}$.

An unusually abrupt sudden commencement on the Earth current record ${ }^{3}$ at College was also observed at 1351 A.s.T. Although sudden commencements are not rare in the Earth current records, they are usually preceded by some sort of activity. During the hour before the sudden commencement the maximum range of activity in the geographical north-south component was $16 \mathrm{mV} . / \mathrm{km}$. At 1351 the trace was abruptly displaced $-572 \mathrm{mV} . / \mathrm{km}$. In less than 30 sec. the trace recovered and went $+410 \mathrm{mV} . / \mathrm{km}$. A negative deflexion of the trace corresponds to a northerly directed electron current in the Earth. For the next $3 \mathrm{hr}$. the trace oscillated about $150 \mathrm{mV}$./ $\mathrm{km}$. with a dominant period of about $2 \mathrm{~min}$. Strong activity continued through the night, and storms occurred during the next two nights.

A red auroral are was observed later that day commencing in the north about 1645 A.S.T., reaching the zenith at about 1720 and fading by 1745 .

$$
\begin{aligned}
& \text { E. M. Wescot' } \\
& \text { J. H. Pope } \\
& \text { D. O. DyeR } \\
& \text { W. H. CAMPBelL }
\end{aligned}
$$

Geophysical Institute,

University of Alaska, College, Alaska.

"Pope, J. H., "An Investigation of Whistlers and Chorus at High Latitudes", Sci. Rep. No. 4, AF 19(604)-1859, Geophys. Inst. Univ. of Alaska (1959).

? Campbell, W. H., J. Geophys. Res., 64, 1819 (1959).

${ }^{3}$ Hessler, V. P., and Wescott, E. M., "Rapid Fluctuations in Earth Currents at College", Sci. Rep." No. 1, $A F$ 19(604)-3075, Univ. of Alaska (Jan. 1959).

\section{Continental Drift}

IN recent years the question of continental drift has received renewed attention mainly as a result of palæomagnetic studies. The general consensus of opinion appears now to look with favour upon this hypothesis. No attempt will be made here to summarize all the supporting evidence-rather the purpose of this communication is to point out a difficulty with such a theory. This is based in part on measurements of the flow of heat through the Earth. Certainly far too few heat-flow measurements have been made to draw any quantitative conclusions. Nevertheless, in spite of quite a large range in the measurements of the flow of heat through the ocean floors, the average flow from oceanic and continental areas is approximately the same. There are also many cases where the oceanic flow of heat is greater than the average value through the continents. These results were unexpected on the basis of the radioactive content of typical oceanic and continental crustal rocks existing near the Earth's surface.

It is a very real problem to find sources of heat beneath the ocean floors. The whole of the observed continental heat flow could be produced by the uranium, thorium and potassium contained in about $25 \mathrm{~km}$. of granite. Granitic type rocks are almost completely absent under the oceans-typical oceanic rocks being basalt the radioactive content of which is only about 30 per cent of that of continental rocks. Bullard, Maxwell and Revelle ${ }^{1}$ have shown that heat production in the sediments due to biological activity, radioactivity and other processes such as chemical weathering cannot account for more than 1 per cent of the observed values. Again, the oceanic crust, being relatively thin and composed mainly of basaltic materials, can produce at most 10 per cent of the observed values. The remaining heat must therefore come from the mantle. There is thus a striking difference between the mantle under the oceans and under the continents. Hence, if a continent, with its more radioactive crust, were to drift over an oceanic area, with its more radioactive mantle, much higher continental heat flows than are observed would be expected.

The distribution of heat sources in the mantle under the oceans is quite critical if melting at depth is to be avoided. A distribution of radioactivity to depths greater than $200 \mathrm{~km}$. would lead to temperatures above the melting point. On the other hand, a distribution of radioactivity through the upper 200 $\mathrm{km}$. of the mantle would require a much greater radioactive concentration than that found in ultrabasic rocks or stony meteorites. A deeper distribution of radioactive heat sources without producing melting would be possible if rocks at depth have a much higher thermal conductivity than is generally assumed, or by convection in the mantle.

It may be argued that the variations observed in the oceanic heat flow are due to convection currents in the mantle. Thus, for example, the recent high values found by Von Herzen ${ }^{2}$ along the East Pacific Rise with areas of low heat flow flanking it may be due to a large convective cell in the upper part of the mantle. But if such an explanation is true, it is difficult to see why convection cells should be confined to the oceanic mantle and not be present under the continents, where the average heat-flow values show considerably less variation. 